\title{
夏秋ギクの親株養成における栽培条件の違いが挿し穂収量と苗質に及ぼす影響
}

\author{
谷川孝弘 *・國武利浩 ・中村知佐子・山田明日香・巣山拓郎・佐伯一直 \\ 福岡県農業総合試験場８18-8549＼cjkstart福岡県筑紫野市大字阿志岐
}

\section{Effects of Culturing Methods of Mother Plants on Yield of Cuttings and Quality of Rooted Cuttings in Summer-to-Autumn-flowering Chrysanthemum morifolium Ramat.}

Takahiro Tanigawa*, Toshihiro Kunitake, Chisako Nakamura, Asuka Yamada, Takuro Suyama and Kazunao Saeki

Fukuoka Agricultural Research Center, Chikushino, Fukuoka 818-8549

\begin{abstract}
The effects of soil or soilless culture of mother plants on the yield of cuttings and the quality of rooted cuttings were examined in the summer-to-autumn-flowering chrysanthemum 'Seiun'. The yield of cuttings in soilless culture was about two times that in soil culture. Stem lengths of rooted cuttings taken from mother plants grown in soilless culture were longer and the number of leaves greater compared with those in soil culture. Especially, there was less premature budding of rooted cuttings taken from mother plants grown in soilless culture than those grown in soil culture. We also investigated the effects of cutting time, concentration of the nutrient solution, planting density, and shading treatment of mother plants cultivated in a soilless culture. The yield of cuttings grown in soilless culture was greatest for a planting density of 25.6 per $\mathrm{m}^{2}$ and with an intermediate concentration (nitrogen concentration was $142 \mathrm{ppm}$ ). It was clear that the stem length of rooted cuttings became shorter when cuttings from the mother plant were taken later and the concentration of nutrient solution was lower. Mother plants in the greenhouse were shaded from ambient daylight (control) using cheesecloth between June and August. The yield of cuttings taken from mother plants under the control conditions increased and the rooting of cuttings improved with increasing light intensity. The above results are considered applicable to the cultivation of mother plants of summer-to-autumn-flowering chrysanthemum.
\end{abstract}

Key Words : cutting production, Dendranthema grandiflorum, nutrient solution, premature budding, stock plants キーワード：培養液，母株，キク，挿し穗生産，早期発蕾

\section{緒言}

キク切り花の周年生産は, 秋ギクを用いた $10 \sim 6$ 月出荷 および夏秋ギクを用いた 6 〜 10 月出荷により成立してい

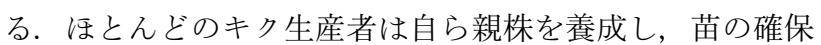
から切り花生産までを行って扣り，親株養成から苗生産に 要する労力は, 切り花生産まで含めた全体の約 $12 \%$ 占め る (谷川, 1999a). なかでも夏秋ギクの親株養成では, 前 年に収穫した切り株を $10 \sim 12$ 月にかけてハウス内に定植 する. そして 6〜7月出荷の作型では, 八ウス内の最低気 温を約 $13^{\circ} \mathrm{C}$ と, $1 \sim 2$ 月に側枝の伸長を促して挿し穂を 得, 挿し芽床で発根させた後， $2 \sim 3$ 月に戒場に定植して いる. また $8 \sim 9$ 月出荷の作型では, 無加温八ウスで親株 を養成し, 随時摘心を行って側枝数を増やし, 挿し穂を得 て発根させた後， $4 \sim 6$ 月に定植している.

夏秋ギクの生産者は，6〜10月出荷に用いる苗生産のた めの労力低減を目的に, 親株からの採穂を 3 か月以上続け

2009 年 1 月 14 日 受付. 2009 年 8 月 12 日 受理.

* Corresponding author. E-mail: tanigawa@farc.pref.fukuoka.jp
て行う場合が多い。しかし，スプレーギクや秋ギクでは, 同一の親株から長期間に拈よんで採穂を繰り返すと，挿し 穂の収量が減少することが確認されている（Cockshull・ Kofranek, 1985; 谷川, 1999a, 2001)。 また，発根苗の根の成 長量が低下し（de Ruiter, 1993; Moe, 1988）, 定植後の茥の伸 長不良 (Andersen・Bertram, 1992; Kofranek, 1980; 谷川, 1999b, 2001）など，「苗質」の低下が生じることも報告され ている，夏秋ギクの親株養成においても，同様の問題が提 起されている（川田，1993）。さらに夏秋ギクでは，親株の 加齢にともない，発根苗の定植後に早期発蕾（柳芽）が多 発することから，これらを防止するための親株養成技術の 確立が重要な課題となっている（川田，1993; Kawata・ Toyota, 1982; 川田ら, 1987).

ヨーロッパでは，スプレーギクの苗と切り花の生産が分 業化され，苗生産の専業経営が成立している (de Jong, 1981; Machin・Scopes, 1978）。そのため，挿し穂収量の減少や発 根苗の苗質低下を防止するための親株養成法に関する研究 が精力的に行われてきた。 たとえば，親株養成のための培 養液濃度と挿し穂生産との関係について, 挿し穂収量は, 親 株の水耕栽培に用いる培養液の窒素濃度が $160 \mathrm{ppm}$ のき 
に最大となった（Röber, 1976）。また，栽植密度について， Kofranek（1980）は親株の定植間隔を調整することで側枝の 伸長が促進され，多くの挿し穂が得られることを明らかに した，さらに，Schoellhornら（1996）は親株養成に用いる 光量を増やすことで側枝数が増加することを確認した.

一方, Röber ・Reuther（1982）は, 親株の水耕栽培に用 いる培養液の窒素濃度が $112 \mathrm{ppm}$ のときに発根苗の定植後 の茎長が長くなり，葉数が最も多くなることを報告してい る. また, Borowskiら（1981）は, 親株養成に用いる光量 を増やすことで発根苗の根の成長量が増加し, 定植後の茎 伸長が長くなることを確認した。

以上のように, これまでの研究により, 親株栽培に用い る培養液や栽植密度, 光条件の違いが插し穗の収量や発根 苗の苗質に影響を及洁すことが示唆されている。しかし， これらの知見はいずれもヨーロッパで主に栽培されている スプレーギクを用いた実験により得られたものであり，わ が国で広く栽培されている一輪ギクでも同様の影響がみら れるかどらかは明らかにされていない．

一輪ギクの切り花生産に用いられている秋ギクの親株養 成については, 谷川（1999a,b）や谷川ら（1995）が, ロッ クウールを培地とした養液栽培を行らことにより, 土耕栽培 と比較して挿し穂の収量が増加し, 発根苗の定植後の茎長が 長くなることを報告した。 また，養液栽培の培地として， ロックウールよりも安価で, 使用後の処分が容易な粉砕スギ 皮を用いると, ロックウール耕の場合とほとんど同質の苗が 得られることも確認されている (谷川, 2001)。乙かし, 秋 ギクと同様に一輪ギクの切り花生産に用いられている夏秋 ギクの親株養成に関する研究事例はほとんどない.

本研究では，夏秋ギクの親株養成に抢ける插し穂収量の 増加や発根苗の苗質改善につながる新たな知見を得ること を目的とし，粉砕スギ皮を培地とした養液栽培と慣行の土 耕栽培でそれぞれ養成した親株について，挿し穂収量や発 根苗の定植後の成長を比較した。また，親株を養液栽培し たときの採穂時期, 培養液濃度, 栽植密度捻よび遮光程度 の違いが挿し穂の収量や発根苗の根の成長量拈よび発根苗 の定植後の生育に及ぼす影響について検討した.

\section{材料および方法}

\section{1. 共通する材料および方法}

2005 年に夏秋ギク ‘精雲’を供試材料とし, 硬質板八ウ スに設置した粉砕スギ皮（日田資源開発，日田市）を培地 とする養液栽培装置（第 1 図）を用い，親株の養成を行っ た. 栽培装置の 1 ベッドの長さは $12 \mathrm{~m}$, 幅 $90 \mathrm{~cm}$ とした. 培養液は, 大塚八ウス 1 号, 2 号抢よび 5 号 (大塚化学, 大 阪市）を用いて作製した (第 1 表)。培養液の給液は親株の 定植 1 週間前に開始し， 1 日当たり 3 回（9:00，12:00 お。 び 17:00), 廃液量が給液量の約 $20 \%$ となるようと給液量を 調節し, 1 ベッドに 1 回当たり 10 分間, 約 $20 \mathrm{~L}$ を掛け流した. 親株に対し，定植直後から白熱灯（75 W，東芝ライテッ

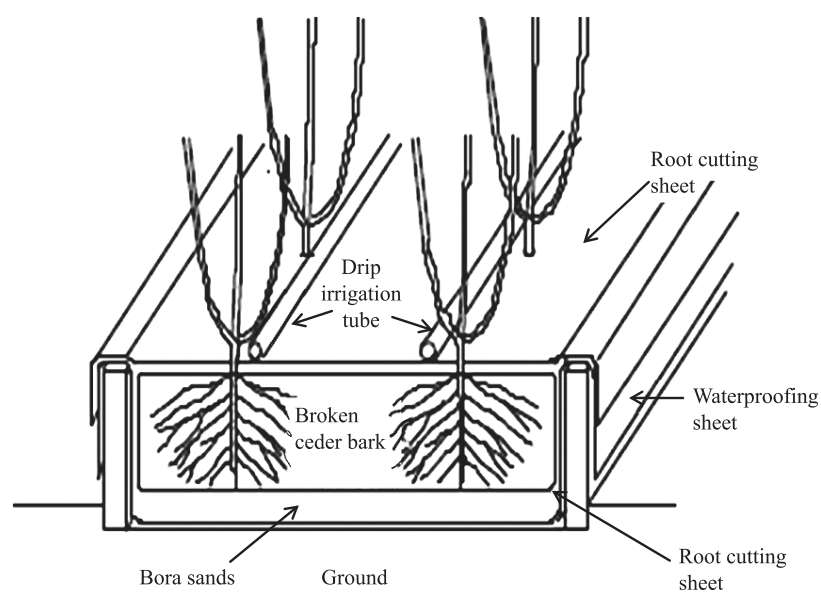

Fig. 1 Soilless culture using broken cedar bark as a culture medium.

Table 1 Concentration of each nutrient constituent with soilless culture under three different electric conductivities (EC).

\begin{tabular}{lccc}
\hline \hline \multirow{2}{*}{$\begin{array}{c}\text { Nutrient } \\
\text { constituent }\end{array}$} & \multicolumn{3}{c}{$\begin{array}{c}\text { Concentration of nutrient solution } \\
\left.\text { (Electric conductivety }\left[\mathrm{EC} \mathrm{dS} \cdot \mathrm{m}^{-1}\right]\right)\end{array}$} \\
\cline { 2 - 4 } & $\begin{array}{c}\text { Low (1.0) } \\
(\mathrm{ppm})\end{array}$ & $\begin{array}{c}\text { Middle (1.5) } \\
(\mathrm{ppm})\end{array}$ & $\begin{array}{c}\text { High }(2.0) \\
(\mathrm{ppm})\end{array}$ \\
\hline Total-N & 95.00 & 142.00 & 189.00 \\
$\left(\mathrm{NH}_{3}-\mathrm{N}\right)$ & 82.00 & 123.00 & 164.00 \\
$\left(\mathrm{NO}_{4}-\mathrm{N}\right)$ & 11.00 & 16.00 & 21.00 \\
$\mathrm{P}_{2} \mathrm{O}_{5}$ & 48.00 & 72.00 & 96.00 \\
$\mathrm{~K}_{2} \mathrm{O}$ & 165.00 & 247.00 & 329.00 \\
$\mathrm{CaO}$ & 69.00 & 104.00 & 138.00 \\
$\mathrm{MgO}$ & 24.00 & 36.00 & 48.00 \\
$\mathrm{MnO}$ & 1.10 & 1.70 & 2.20 \\
$\mathrm{~B}_{2} \mathrm{O}_{3}$ & 1.10 & 1.70 & 2.20 \\
$\mathrm{Fe}$ & 2.50 & 3.80 & 5.00 \\
$\mathrm{Cu}$ & 0.02 & 0.03 & 0.04 \\
$\mathrm{Zn}$ & 0.08 & 0.11 & 0.15 \\
\hline
\end{tabular}

ク，横須賀市）を用いて暗期中断（22:00〜 2:00）を行い， 花芽形成を抑制した。また，硬質板ハウスは夜間最低気温 $15^{\circ} \mathrm{C}$ で加温し，日中の八ウス内の気温が $25^{\circ} \mathrm{C}$ 以上の場合 には側空拈よび天空を開放して換気した。その結果，八ウ ス内の最低気温は 5 月中旬頃まで $15^{\circ} \mathrm{C}$ で維持されたが， 6 月下旬には $22 \sim 24^{\circ} \mathrm{C}$ にまで上昇した（第 2 図）。一方，最 高気温は 5 月中旬頃まで $30^{\circ} \mathrm{C}$ 前後で変動したが, 6 月下旬 には $40^{\circ} \mathrm{C}$ にで達した。

親株からの採穂は毎週 1 回, $10 \mathrm{~cm}$ 以上に伸長したすべ ての側枝について行った．插し穂の長さは約 $10 \mathrm{~cm} ，$ 本葉 約 5 枚とし，得られた挿し穂の本数を調查し，插し穂収量 とした。 また発根苗の根の成長量を調査するため，挿し穂 を本葉 3 枚, 長さ約 $7 \mathrm{~cm}$ 亿調整し, 無加温の硬質板八ウス でボラ砂を用土として插し芽した。そ後，ミスト散水を 行って発根させ，插し芽から 2 週間後に発根苗の根数，根 長を測定した

発根苗は，挿し芽 2 週間後に 1 栽培箱（長さ $60 \mathrm{~cm} \times$ 幅 


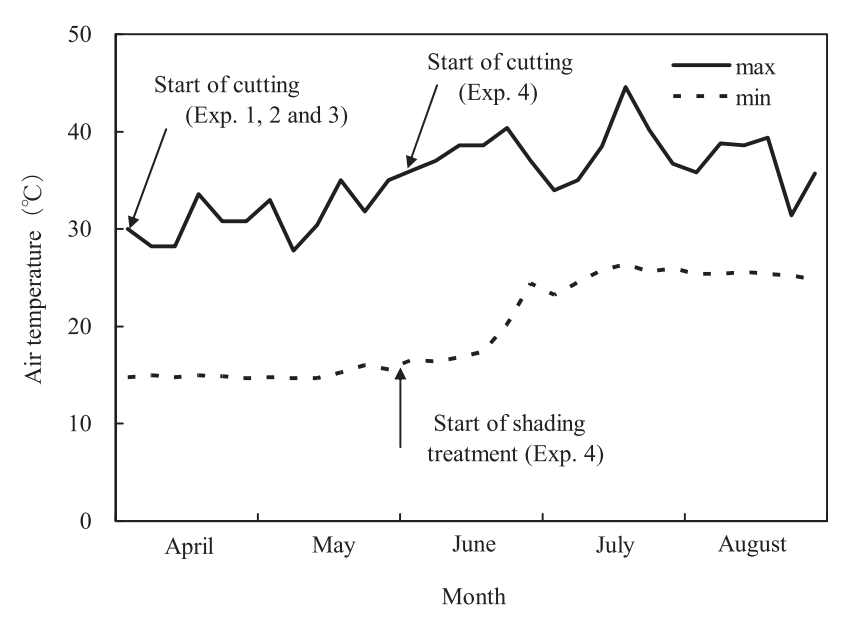

Fig. 2 Maximum and minimum air temperatures at 5-day intervals during the experimental period in the greenhouse in which the mother plants were grown.

$18 \mathrm{~cm} \times$ 深さ $15 \mathrm{~cm})$ 当たり 10 株ずつ定植した. 用土は, 田 土,メトロミックス350 (Sun Gro Horticulture Distribution Inc., New York), 腐葉土拈よびボラ砂をそれぞれ容量比で $5: 2$ : $2: 1$ に混合して用いた。 それぞれの栽培箱に，1 箱当たり 緩効性肥料 $\left(\mathrm{N}: \mathrm{P}_{2} \mathrm{O}_{5}: \mathrm{K}_{2} \mathrm{O}=13: 16: 10\right.$, チッソ旭, ロン グトータル花卉 1 号，100日タイプ [100 日間で総肥料成分 の約 $80 \%$ を溶出する]，東京）を $30 \mathrm{~g}$ 施用し，ガラスハウ ス内に置き, 朝 1 回灌水を行った. ガラスハウスは無加温 とし, 日中の気温が $25^{\circ} \mathrm{C}$ を超える場合に側空と天空を開 放して換気した。 発根苗も定植直後から $75 \mathrm{~W}$ 白熱灯を用 いて暗期中断（22:00〜2:00）を行った. 定植 6 週間後に 茎長, 葉数, 平均節間長拈よび早期発蕾率を調査した.

\section{2. 親株養成の栽培法の違いが挿し穂収量と苗質に及ぼす 影響（実験 1)}

土耕栽培と養液栽培による親株養成を行い, 栽培法の違 いが挿し穂の収量と発根苗の苗質に及ぼす影響について検 討した. 土耕栽培は, 福岡県内のキク産地に扣ける慣行栽 培に基づき, $80 \mathrm{~cm}$ のベッド幅に株間 $20 \mathrm{~cm}$ の 4 条植え (栽 植密度 : 25 株・ $\mathrm{m}^{-2}$ ) で行った. 定植 2 週間前に前述の緩 効性肥料を $1 \mathrm{~m}^{2}$ 当たり $30 \mathrm{~g}$ 施用した. 一方, 養液栽培で は $90 \mathrm{~cm}$ のベッド幅に株間 $17.4 \mathrm{~cm}$ の 4 条植え（栽植密度： 25.6 株・ $\left.\mathrm{m}^{-2}\right)$ とし, 慣行の栽植密度とほぼ同等となるよう に定植した. 培養液は中濃度（第 1 表）のものを使用した.

土耕栽培と養液栽培はいずれも2 月 6 日に親株を定植し, 2 月 20 日拈よび 3 月 15 日に摘心し， 4 月 6 日〜 6 月 29 日 まで採穂し, 挿し穂の収量を調査した。 ただし, 土耕栽培 では暗期中断処理の実施にもかかわらず，6月初旬から親 株に早期発蕾が認められたため，5月末で採穂を中止した. 4 月 6 日と 5 月 4 日の 2 回, 親株から採穂した挿し穂の全 窒素（T-N）, カリウム $(\mathrm{K})$, カルシウム $(\mathrm{Ca})$, マグネシ ウム $(\mathrm{Mg})$ およびナトリウム $(\mathrm{Na})$ 含有率について分析 した. 同時期に採穂した別の插し穂を発根させ，その発根 苗について定植 6 週間後の茎長, 葉数, 平均節間長打よび
早期発蕾率を調査した。

\section{3. 親株の養液栽培における培養液濃度および栽植密度の 違いが挿し穂の収量に及ぼす影響（実験 2）}

濃度が異なる 3 種類の培養液（第 1 表）を用い, 12.8 , 19.2，25.6 抢よび 32.0 株・ $\mathrm{m}^{-2}$ の栽植密度でそれぞれ親株 の養成を行った. 1 ベッド当たり 1 種類の培養液を施用し, 各ベッドに親株を 4 条植えとした，また，1ベッドを 4 区 分し，各区の株間を $34.7,23.1,17.4$ および $13.9 \mathrm{~cm}$ とした (1 区当たりの定植株数はそれぞれ $34,52,68$ および 86 株).

実験 1 と同じ時期に同じ方法で插し穂の収量を調査した. また，各ベッドの培地に含まれる培養液を毎週 1 回，スポ イドで採取し，ECを測定した。

\section{4. 親株の養液栽培における培養液濃度と採穂時期の違い が苗質に及ぼす影響（実験 3）}

実験 2 で使用した 3 種類の培養液を用い，25.6 株・ $\mathrm{m}^{-2}$ の栽植密度で親株の養液栽培を行った． 4 月 6 日， 5 月 4 日，6月 1 日拈よび 6 月 29 日に採穂した挿し穂を挿し芽し て発根させ，発根苗の定植 6 週間後の茥長，葉数，平均節 間長および早期発蕾率を調査した。

\section{5. 親株の養液栽培における遮光処理が挿し穂収量と苗質 に及ぼす影響（実験 4）}

4 月 5 日に親株を 25.6 株・ $\mathrm{m}^{-2}$ の栽植密度で定植し，中 濃度（第 1 表）の培養液を用いて栽培を行った。 4 月 19 日 および 5 月 10 日に摘心を行い，6月 1 日から遮光率が 20 , 50 抢よび70\%となるように寒冷紗を用いて遮光処理を開始 した. 6 月 2 日から毎週 1 回の採穂を繰り返し，8月末まで 挿し穂収量を調査した。 また，8 月 5 日に採穂した挿し穂 は挿し芽して発根させ, 発根苗の根長, 根数, 根重 (乾物) および地上部重（乾物）を調査した。なお， 7 月 25 日の晴 天日の 13:00に拈いて，八ウス内の無遮光（対照）区，20, 50 抢よび70\%遮光区に打ける5か所の平均照度はそれぞれ 7.4，5.8，3.6 および $2.2 \mathrm{klx}$ であった。

\section{結果}

\section{1. 親株養成の栽培法の違いが挿し穂収量と苗質に及ぼす 影響 (実験 1)}

親株養成を土耕栽培または養液栽培で行った場合の $1 \mathrm{~m}^{2}$ 当たり月別挿し穂収量を第 3 図に示す。養液栽培を行った 場合の挿し穂収量は，4月で 303 本，5月で 478 本となり, 土耕栽培を行った場合に比べ約 2 倍の収量が得られた。 た，6月では 632 本となり，さらに収量が増加することを 確認した.

土耕栽培または養液栽培で養成した親株から 4 月 6 日と 5 月 4 日に採穂した插し穂を発根させ，発根苗の定植 6 週 間後の生育を比較した結果を第 2 表に示す．採穂日にかか わらず，養液栽培した親株から得た発根苗の茎長は土耕栽 培よりも長くなった。 また，発根苗の葉数は，4月 6 日採 穂の苗では栽培法の違いによる差は認められなかったが, 5 月 4 日採穂の苗では養液栽培の方が土耕栽培に比べて葉 


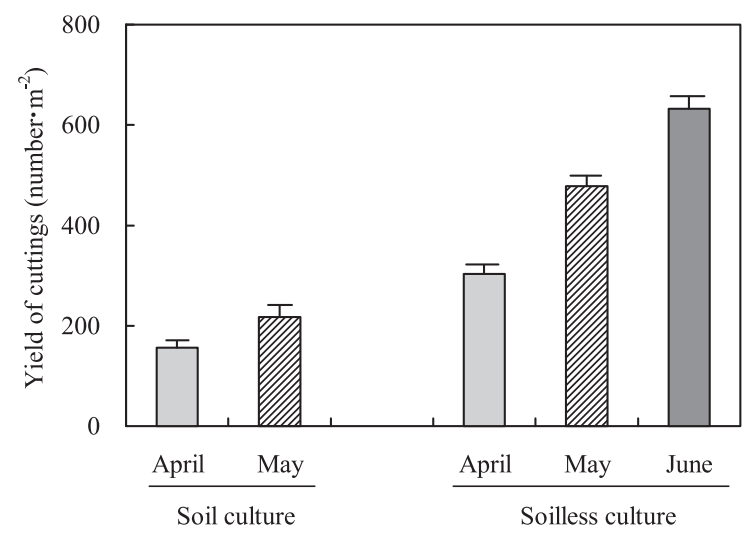

Fig. 3 Monthly yield (number) of cuttings taken from the mother plants cultivated with soil culture or soilless culture. As lateral branches of the mother plants with soil culture formed premature budding in early-June, cuttings could not be taken from the mother plants in June.

Vertical bars are the SE $(n=3)$.
数が増加した. 発根苗の平均節間長は，4月 6 日採穂の苗 では養液栽培が土耕栽培に比べ長くなったが，5月 4 日採 穂の苗では栽培法の違いによる差は認められなかった。発 根苗における早期発蕾率は，4月 6 日採穂の苗ではいずれ の栽培法でも $0 \%$ であったが, 5 月 4 日採穂の苗では養液栽 培で 5.4\%と低く，土耕栽培では 58.6\% と増加した。

4 月 6 日と 5 月 4 日に採穂した挿し穂の成分含有率を分 析した結果を第 3 表に示す，各成分の含有率は，採穂日が 同じ場合，土耕栽培と養液栽培との間で栽培法の違いによ る差は認められなかった，一方，窒素とカリウムの含有率 は，4月 6 日採穗の挿し穂と比較して 5 月 4 日採穂の挿し 穂で有意に低下した.

\section{2. 親株の養液栽培における培養液濃度および栽植密度の 違いが挿し穂の収量に及ぼす影響（実験 2）}

異なる濃度の培養液を用い，異なる栽植密度で親株を養 成したときの挿し穂収量を第 4 図に示す。別挿し穂収量 は，培養液濃度や栽植密度の違いにかかわらず， $4 \sim 6$ 月 にかけて増加した。栽植密度が同じ場合， $4 \sim 6$ 月の総挿

Table 2 Effects of cutting date and planting system of mother plants on growth and premature budding of rooted cuttings propagated from the mother plants of the summer-to-autumn-flowering chrysanthemum 'Seiun'z.

\begin{tabular}{|c|c|c|c|c|c|}
\hline $\begin{array}{l}\text { Cutting date } \\
\text { (day/month) }\end{array}$ & $\begin{array}{l}\text { Planting } \\
\text { sytem }\end{array}$ & $\begin{array}{l}\text { Stem length } \\
\quad(\mathrm{cm})\end{array}$ & $\begin{array}{l}\text { Number of } \\
\text { leaves }\end{array}$ & $\begin{array}{l}\text { Mean internode } \\
\text { length }(\mathrm{cm})\end{array}$ & $\begin{array}{c}\text { Portion of premature } \\
\text { budding }(\%)\end{array}$ \\
\hline \multirow[t]{2}{*}{ 6/April } & Soil culture & $63.4 b^{y}$ & $33.1 \mathrm{a}$ & $1.92 \mathrm{c}$ & $0.0 \mathrm{c}^{\mathrm{x}}$ \\
\hline & Soilless culture & $65.7 \mathrm{a}$ & $33.7 \mathrm{a}$ & $1.95 \mathrm{~b}$ & $0.0 \mathrm{c}$ \\
\hline \multirow[t]{2}{*}{ 4/May } & Soil culture & $58.6 \mathrm{~d}$ & $29.6 \mathrm{c}$ & $1.98 \mathrm{a}$ & $5.4 \mathrm{~b}$ \\
\hline & Soilless culture & $60.3 \mathrm{c}$ & $30.6 \mathrm{~b}$ & $1.97 \mathrm{ab}$ & $58.6 \mathrm{a}$ \\
\hline \multicolumn{6}{|l|}{ Analysis of variance ${ }^{\mathrm{w}}$} \\
\hline Cutting date (a) & & $* *$ & $* *$ & $* *$ & $* *$ \\
\hline Planting system (b) & & $* *$ & $*$ & NS & $* *$ \\
\hline $\mathrm{a} \times \mathrm{b}$ & & NS & NS & NS & $* *$ \\
\hline
\end{tabular}

${ }^{\mathrm{z}}$ Rooted cuttings were planted in plant boxes two weeks after cutting and the plant boxes were placed in the greenhouse. Measurements were recorded 6 weeks after planting.

${ }^{\mathrm{y}}$ Mean separation within the column by Tukey's HSD test, $5 \%$ level.

${ }^{\mathrm{x}}$ Mean separation within the column by $\chi^{2}$ test, $5 \%$ level.

${ }^{\mathrm{w}} \mathrm{NS}, *$ and $* *$ indicate non-significance and a significant difference at $P<0.05$ and 0.01 , respectively.

Table 3 Effects of cutting date and planting system of mother plants on the component concentrations by percentage of cuttings taken from the mother plants in the summer-to-autumn-flowering chrysanthemum 'Seiun'.

\begin{tabular}{|c|c|c|c|c|c|c|}
\hline $\begin{array}{l}\text { Cutting date } \\
\text { (day/month) }\end{array}$ & Planting sytem & $\begin{array}{l}\text { Total-nitrogen } \\
\qquad \begin{array}{c}(\mathrm{T}-\mathrm{N}) \\
(\%)\end{array}\end{array}$ & $\begin{array}{l}\text { Potassium } \\
\qquad \begin{array}{l}(\mathrm{K}) \\
(\%)\end{array}\end{array}$ & $\begin{array}{l}\text { Calcium } \\
\qquad \begin{array}{c}(\mathrm{Ca}) \\
(\%)\end{array}\end{array}$ & $\begin{array}{c}\text { Magnesium } \\
(\mathrm{Mg}) \\
(\%)\end{array}$ & $\begin{array}{l}\text { Sodium } \\
(\mathrm{Na}) \\
(\%)\end{array}$ \\
\hline 6/April & $\begin{array}{c}\text { Soil culture } \\
\text { Soilless culture }\end{array}$ & $\begin{array}{l}4.45 \mathrm{a}^{\mathrm{z}} \\
4.38 \mathrm{a}\end{array}$ & $\begin{array}{l}5.87 \mathrm{a} \\
5.92 \mathrm{a}\end{array}$ & $\begin{array}{l}0.14 \mathrm{a} \\
0.15 \mathrm{a}\end{array}$ & $\begin{array}{l}0.25 \mathrm{a} \\
0.27 \mathrm{a}\end{array}$ & $\begin{array}{l}0.04 \mathrm{a} \\
0.05 \mathrm{a}\end{array}$ \\
\hline 4/May & $\begin{array}{c}\text { Soil culture } \\
\text { Soilless culture }\end{array}$ & $\begin{array}{l}4.07 \mathrm{~b} \\
3.95 \mathrm{~b}\end{array}$ & $\begin{array}{l}5.26 \mathrm{~b} \\
5.39 \mathrm{~b}\end{array}$ & $\begin{array}{l}0.16 \mathrm{a} \\
0.15 \mathrm{a}\end{array}$ & $\begin{array}{l}0.23 \mathrm{a} \\
0.25 \mathrm{a}\end{array}$ & $\begin{array}{l}0.04 \mathrm{a} \\
0.04 \mathrm{a}\end{array}$ \\
\hline $\begin{array}{l}\text { Analisis of var } \\
\text { Cutting date } \\
\text { Planting sys } \\
a \times b\end{array}$ & & $\begin{array}{c}* \\
\text { NS } \\
\text { NS }\end{array}$ & $\begin{array}{l}* * \\
\text { NS } \\
\text { NS }\end{array}$ & $\begin{array}{l}\text { NS } \\
\text { NS } \\
\text { NS }\end{array}$ & $\begin{array}{l}\text { NS } \\
\text { NS } \\
\text { NS }\end{array}$ & $\begin{array}{l}\text { NS } \\
\text { NS } \\
\text { NS }\end{array}$ \\
\hline
\end{tabular}

\footnotetext{
${ }^{\mathrm{z}}$ Mean separation within the column by $\chi^{2}$ test, $5 \%$ level.
}

${ }^{\mathrm{y}} \mathrm{NS}, *$ and $* *$ indicate non-significant and a significant difference at $P<0.05$ and 0.01 , respectively. 
し穂収量は，低濃度の培養液と比較して中濃度および高濃 度の培養液で多くなった。 しかし，中濃度と高濃度の培養 液間の総插し穂収量の差は小さかった。一方, 低濃度の培 養液を用いた場合， $4 \sim 6$ 月の総挿し穂収量は栽植密度が 高いほど増加した。 それに対して中濃度と高濃度の培養液 を用いた場合の総挿し穂収量は，栽植密度が 25.6 株・ $\mathrm{m}^{-2}$ のときに，ほかの栽植密度よりも多くなった。最も挿し穂

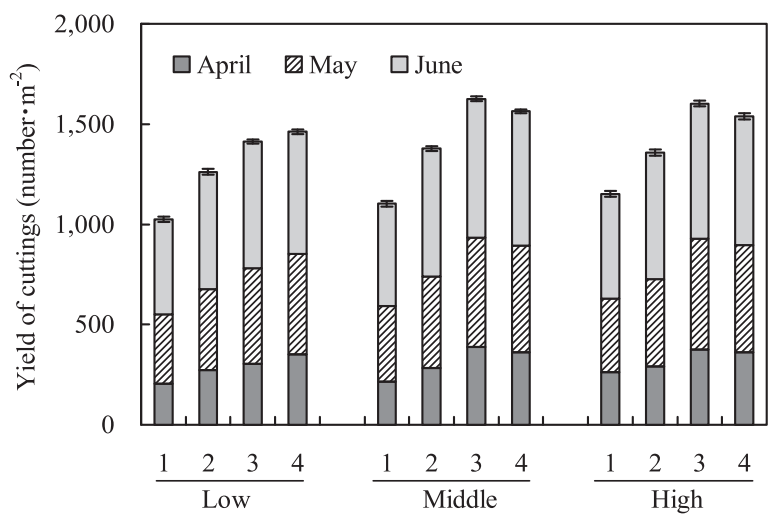

Planting density / Concentration of nutrient solution $\left(\mathrm{dS} \cdot \mathrm{m}^{-1}\right)$

Fig. 4 Effect of cutting time, planting density and concentration of nutrient solution of mother plants cultivated with soilless culture on the yield of cuttings taken from the mother plants. Planting density: $1,12.8 \mathrm{~m}^{-2} ; 2,19.2 \mathrm{~m}^{-2} ; 3,25.6 \mathrm{~m}^{-2} ; 4$, $32.0 \mathrm{~m}^{-2}$. Low, Middle, and High indicate different nutrient concentration (Table 1).

Vertical bars are the SE $(n=3)$.
収量が多かったのは，中濃度の培養液を用い， 25.6 株・ $\mathrm{m}^{-2}$ の栽植密度で親株を栽培した場合であった.

各ベッドの培地に含まれる培養液の EC を測定した結果を 第 5 図に示す。いずれの濃度の培養液を用いたベッドでも， 培地の EC は栽培期間を通じてほぼ一定の值に保たれていた。

3. 親株の養液栽培における培養液濃度と採穂時期の違い が苗質に及ぼす影響（実験 3）

異なる濃度の培養液を用い, 25.6 株・ $\mathrm{m}^{-2}$ の栽植密度で 親株を栽培し，異なる時期に採穂して得た発根苗について 茥長，葉数，平均節間長扣よび早期発蕾率を調査した結果 を第 4 表に示す．茥長，葉数および平均節間長は，培養液 濃度にかかわらず，採穂時期が遅くなる汪ど低い值を示し

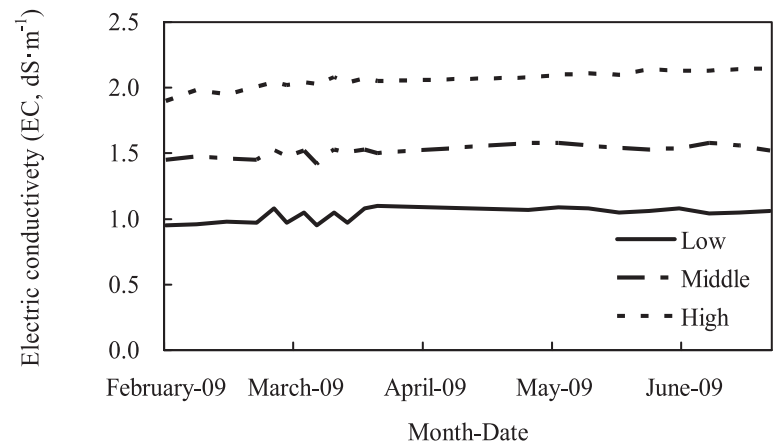

Fig. 5 Changes of electric conductivity (EC) of each nutrient concentration in the medium in which the mother plants were grown during the experimental period. Low, Middle, and High indicate different nutrient concentration (Table 1).

Table 4 Effects of cutting date and concentration of nutrient solution of mother plants cultivated with soilless culture on growth and portion of premature budding of rooted cuttings propagated from the mother plants of 'Seiun'z.

\begin{tabular}{|c|c|c|c|c|c|}
\hline $\begin{array}{l}\text { Cutting date } \\
\text { (day/month) }\end{array}$ & $\begin{array}{l}\text { Concentration of } \\
\text { nutrient solution }\end{array}$ & $\begin{array}{l}\text { Stem length } \\
(\mathrm{cm})\end{array}$ & $\begin{array}{l}\text { Number of } \\
\text { leaves }\end{array}$ & $\begin{array}{l}\text { Mean internode } \\
\text { length }(\mathrm{cm})\end{array}$ & $\begin{array}{l}\text { Portion of premature } \\
\text { budding }(\%)\end{array}$ \\
\hline \multirow[t]{3}{*}{ 6/April } & Low & $65.7 b^{y}$ & $33.7 \mathrm{a}$ & $1.95 \mathrm{a}$ & $0.0 \mathrm{f}^{\mathrm{x}}$ \\
\hline & Middle & $67.8 \mathrm{ab}$ & $33.1 \mathrm{a}$ & $2.05 \mathrm{a}$ & $0.0 \mathrm{f}$ \\
\hline & High & $69.8 \mathrm{a}$ & $34.7 \mathrm{a}$ & $2.01 \mathrm{a}$ & $0.0 \mathrm{f}$ \\
\hline \multirow[t]{3}{*}{ 4/May } & Low & $60.3 \mathrm{e}$ & $30.6 \mathrm{~b}$ & $1.97 \mathrm{a}$ & 5.4 ef \\
\hline & Middle & $63.2 \mathrm{~cd}$ & $31.1 \mathrm{~b}$ & $2.03 \mathrm{a}$ & $1.2 \mathrm{f}$ \\
\hline & High & $62.8 \mathrm{de}$ & $30.6 \mathrm{~b}$ & $2.06 \mathrm{a}$ & $0.0 \mathrm{f}$ \\
\hline \multirow[t]{3}{*}{$1 /$ June } & Low & $44.4 \mathrm{~g}$ & $21.8 \mathrm{e}$ & $2.06 \mathrm{a}$ & $32.4 \mathrm{a}$ \\
\hline & Middle & $48.7 \mathrm{f}$ & $23.8 \mathrm{~d}$ & $2.04 \mathrm{a}$ & $16.8 \mathrm{c}$ \\
\hline & High & $48.6 \mathrm{f}$ & $25.7 \mathrm{c}$ & $1.89 \mathrm{ab}$ & $12.4 \mathrm{~cd}$ \\
\hline \multirow[t]{3}{*}{ 29/June } & Low & $38.0 \mathrm{~h}$ & $23.3 \mathrm{~d}$ & $1.64 \mathrm{c}$ & $24.6 \mathrm{~b}$ \\
\hline & Middle & $44.2 \mathrm{~g}$ & $25.7 \mathrm{c}$ & $1.72 \mathrm{bc}$ & $12.8 \mathrm{~cd}$ \\
\hline & High & $42.5 \mathrm{~g}$ & $24.5 \mathrm{~cd}$ & $1.73 \mathrm{bc}$ & $10.2 \mathrm{de}$ \\
\hline \multicolumn{6}{|c|}{ Analysis of variance ${ }^{w}$} \\
\hline \multicolumn{2}{|c|}{ Cutting date (a) } & $* *$ & ** & $* *$ & ** \\
\hline \multicolumn{2}{|c|}{ Concentration of nutrient solution (b) } & ** & ** & NS & * \\
\hline \multicolumn{2}{|c|}{$\mathrm{a} \times \mathrm{b}$} & ** & ** & NS & NS \\
\hline \multicolumn{6}{|c|}{$\begin{array}{l}{ }^{\mathrm{z}} \text { Rooted cuttings were planted in plant boxes two weeks after cutting and the plant boxes were placed in the greenhouse. Measurements were } \\
\text { recorded } 6 \text { weeks after planting. }\end{array}$} \\
\hline \multicolumn{6}{|c|}{${ }^{\mathrm{y}}$ Mean separation within the column by Tukey’s HSD test, $5 \%$ level. } \\
\hline \multicolumn{6}{|c|}{${ }^{\mathrm{x}}$ Mean separation within the column by $\chi^{2}$ test, $5 \%$ level. } \\
\hline
\end{tabular}


た。 また, 採穂時期が同じ場合, 中濃度および高濃度の培 養液で栽培した親株から得た苗の茎長は, 低濃度の培養液 を用いた場合よりも長くなる傾向が認められた。 一方, 葉 数は, 4 月 6 日と 5 月 4 日採穂の苗では培養液濃度の違い による差は認められなかったが，6月 1 日採穗の苗では高 濃度の培養液で最も多くなり，6月29日採穂の苗では，中 濃度の培養液濃度で最も多くなった。 平均節間長は, 採穂 時期が同じ場合，培養液濃度の違いによる差は認められな かった. 早期発蕾は, 4 月 6 日採穂の苗では認められなかっ た. 一方， 5 月 4 日採穂の苗では, 低濃度执よび中濃度の 培養液でそれぞれ 5.4 および $1.2 \%$ の早期発蕾率が示され, 6 月 1 日と 6 月 29 日採穗の苗ではより高い值 $(12.4 \sim 32.4$ \%扎よび $10.2 ２ 4.6 \%$ ）が示された. また，いずれの採穂 時期においても，培養液濃度が薄い注ど早期発蕾率が高く なる傾向が示された.

\section{4. 親株の養液栽培における遮光処理が挿し穂収量と苗質 に及ぼす影響（実験 4）}

6 月 1 日〜 8 月末まで異なる遮光率で親株を養成したと きの挿し穂収量を第 6 図に示す。別挿し穂収量は, 対照 区と比較して遮光率が高くなる汪ど減少する傾向を示し た. 特に $70 \%$ 遮光区の挿し穂収量は，対照区の $1 / 2$ 以下と なった。

異なる遮光率で栽培した親株から採穂して得た発根苗に ついて根長, 根数, 根重および地上部重を調査した結果を 第 5 表に示す. 8 月 5 日に採穂して插し芽を行った場合の根 長は, 対照区の $2.56 \mathrm{~cm}$ と比較して $20 \%$ 遮光区では $2.24 \mathrm{~cm}$ と有意差がなかった，それに対して，50および 70\%遮光区 ではそれぞれ 1.26 および $0.72 \mathrm{~cm}$ と有意に短くなった。根 数および根重も同様の傾向を示した. 発根苗の地上部重は, 対照区と比較して遮光率が高くなるほど有意に減少した.

\section{考察}

親株の土耕栽培と養液栽培との比較において, 挿し穂収 量は，養液栽培が土耕栽培の約 2 倍と多くなった。 このこ とは，谷川（1999b）が秋ギクを用いて行った結果とほぼ同 じであり，親株の養液栽培がキクの挿し穂収量の増加に広 く有効であることが示唆された，また，夏秋ギクでは，養 液栽培した親株から得た発根苗の茎長や葉数が，土耕栽培 した親株から得た発根苗と比較して増加する傾向があるこ とを確認した。ささらに，養液栽培から得られた発根苗での 早期発蕾の発生が，土耕栽培から得られた発根苗よりも長 期間に拈よんで少なかった。 これらの結果は，スプレーギ クや秋ギクでは報告されて扣らず，本研究で新たに得られ た知見である，以上より，夏秋ギクの切り花生産における 問題，すなわち親株から長期間にわたり採穂することで生 じる挿し穂収量の減少や発根苗の苗質低下, 早期発蕾の発 生（川田，1993）に対し，親株の養液栽培がその解決策と してきわめて有効であることが示された.

土耕栽培および養液栽培した夏秋ギクの親株から得られ

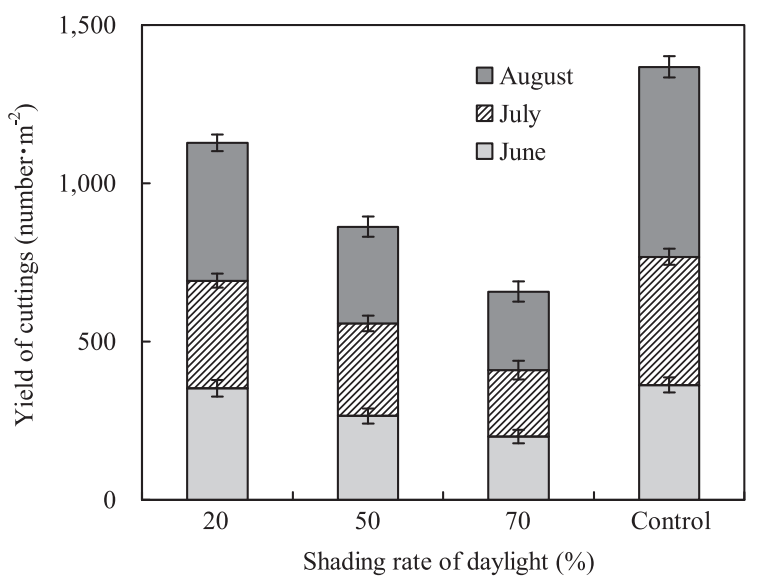

Fig. 6 Effects of the shading rate of daylight in the greenhouse in which the mother plants were cultivated with soilless culture in the summer-to-autumn-flowering chrysanthemum 'Seiun'. Control plants were not shaded. Vertical bars are the SE $(n=3)$.

Table 5 Effects of shading (as a percentage of daylight) in the greenhouse in which the mother plants were cultivated on rooting of cuttings taken from the mother plants on August 5 in the summer-to-autumn-flowering chrysanthemum 'Seiun'z.

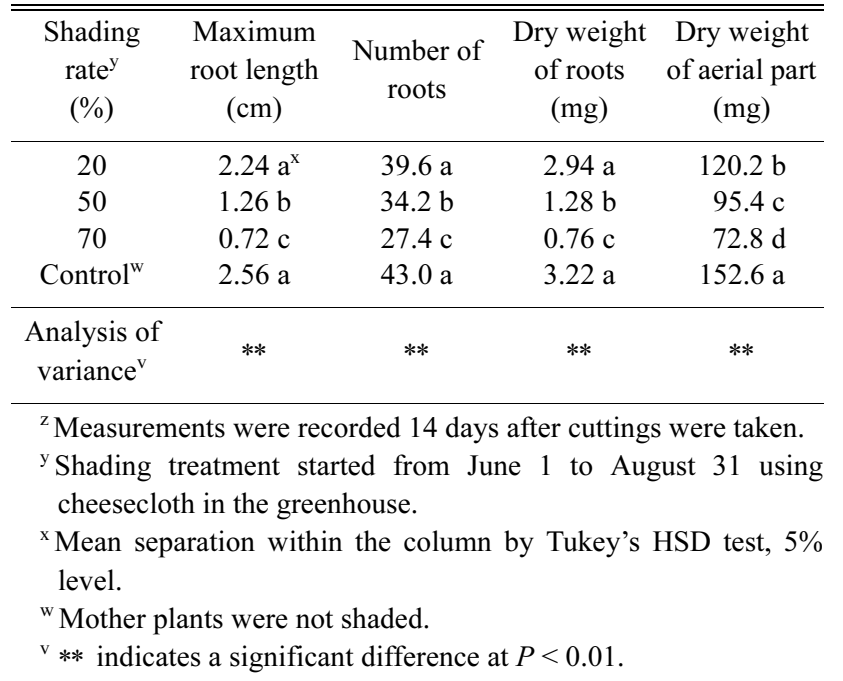

た挿し穂の無機成分含有率を調査したところ，両者間に大 きな差は認められなかった．このことから，夏秋ギクの土 耕栽培に打ける挿し穂収量や苗質低下の要因が，養液栽培 との栄養条件の違いにあるとは考光にくい. 養液栽培では, 土壌中の細菌や糸状菌などによる発根阻害がなく，培養土 の化学的・物理的性質により毛根が健全に発育するため, 親株の齢の進行が土耕栽培よりも抑制されている可能性が 考号れる．この点に関しては，今後さらに検討する必要 がある.

夏秋ギク 親株の養液栽培に括いて，培養液濃度と栽植密 度が插し穂収量に及汸す影響を調べた結果，中濃度（窒素 濃度は $142 \mathrm{ppm}$ ）の培養液を用い，栽植密度を 25.6 株・ $\mathrm{m}^{-2}$ とした場合に挿し穂收量が最大となった。また，25.6株・ 
$\mathrm{m}^{-2}$ の栽植密度では, 中濃度と高濃度（窒素濃度は $189 \mathrm{ppm}$ ) 培養液を用いたときの挿し穂収量に大きな差がなかったこ とから，夏秋ギクの親株養成では，培養液濃度は中濃度を 上限とし，それより高くしても挿し穂収量が増加しないこ とが明らかとなった。 この結果は，秋ギクを用いた谷川 （1999b）やスプレーギクを用いたRöber（1976）の実験で 得られている結果と一致する. 従って, キクでは品種群に かかわらず，挿し穂収量を最大とする親株養成のための培 養液濃度には, 上限の限界值があることが強く示唆される. 一方, Williams・Nelson（1992）は，スプレーギクを用いた 実験で, 培養液濃度と插し穂収量との関係について, 窒素 濃度の低い培養液であっても給液回数を増やすことで, 窒 素濃度の高い培養液と同じ効果が得られることを報告して いる. 今後，秋ギクや夏秋ギクでも同様の結果が得られる かぞらか，検討が必要と思われる.

低濃度（窒素濃度は95 ppm）の培養液を用いた夏秋ギク の親株養成では，栽植密度が高い䚾ど挿し穂収量が増加し た。 それに対して中濃度および高濃度の培養液では, 栽植 密度が 25.6 株・ $\mathrm{m}^{-2}$ で挿し穂収量が最大となり, それより も高い 32.0 株・ $\mathrm{m}^{-2}$ では逆に減少した. これらの結果も, 秋ギクを用いた谷川（1999b）の実験で得られた結果と一致 する. 32.0 株・ $\mathrm{m}^{-2}$ で挿し穂収量が減少したのは，親株の 密植により, 単位面積当たりの側枝数が増加し, 側枝の成 長が阻害され，側枝長が採穂可能な $10 \mathrm{~cm}$ に満たないもの が増加したことが原因と考える。

養液栽培による夏秋ギクの親株養成では, 親株の定植後, 採穂までの期間が長くなるほど, 発根苗の茎長が短くなり, 葉数が減少し, 早期発蕾が増加した。 また, この現象は培 養液濃度が低い注ど顕著にみられた。これは，親株からの 採穂回数が多くなるにつれて親株に形成される側枝数が増 え, 低濃度の培養液ではそれぞれの挿し穂に十分な無機栄 養を供給できなかったことが主たる要因と考えられる. 従って，夏秋ギクの苗質を長期間にわたって一定に維持す るためには，親株養成に打ける培養液濃度は，親株定植後 の初期の段階では低濃度で管理し，側枝数の増加に応じて 徐々に高める方法が適切と考えられるが，これについては 今後さらに検討が必要である.

養液栽培による夏秋ギクの親株養成では，遮光率が高い ほど挿し穂収量が減少し, 挿し芽後の発根苗の根の成長量 も低下した．スプレーギクでは親株養成に用いる光量の増 加により発根苗の根の成長量が増加することが報告されて いるが（Borowskiら，1981），本実験から夏秋ギクでもこ れと矛盾しない結果が示された. キク個体の光合成の飽和 光強度は, 約 $50 \mathrm{klx}$ であることが明らかにされている（谷 川・小林，1991）が，本実験では，無遮光区およびすべて の遮光区に拈いてその光強度よりも低い光条件に長時間お かれた状況下で親株を栽培していたものと考えられる。ま た，苗質を調査した 8 月 5 日時点では，採穂開始後 2 か月 を経過しており，親株の側枝が繁茂した状態のため，下位
節の側枝は低い光強度の条件下で伸長したことが推察され る. 従って，本実験と同様の光条件下で夏秋ギクの親株養 成を行ら場合には，寒冷紗などを用いて常時被覆すること は避けるべきであることが明らかとなった，さらに，親株 の栽培期間中に日照不足が生じると，挿し穂収量や苗質が 低下する可能性があり，挿し穂収量や苗質を一定のレベル に維持するためには，強い光条件下で親株の栽培を継続す ることが重要であることが示唆された。なお， Fischer・ Hansen（1977）は，スプレーギク ‘改良メフォ’の親株を 強光条件で栽培すると挿し穂の発根数が多くなることを報 告している，また，Schoellhornら（1996）は，12 品種のス プレーギクを用いた実験で，親株養成時の光量が多いほど 側枝数が増加することを確認した．このことから，秋ギク や夏秋ギクについても，親株養成時の光量の増加が扦し穂 収量や苗質に及ぼす影響をより詳細に調査する必要がある と考光る.

以上の結果から，夏秋ギクの親株養成では，(1)土耕栽培 と比較して養液栽培を行らことにより約 2 倍の挿し穂収量 が得られること, (2)養液栽培により, 土耕栽培と比較して 苗質が向上すること，(3)養液栽培による親株養成では，採 穂の収量性拈よび苗質の面から中濃度（窒素濃度で約 $140 \mathrm{ppm}$ ）の培養液を用い，栽植密度を 25.6 株・ $\mathrm{m}^{-2}$ とする のがよいこと, (4) $6 〜 8$ 月にかけての親株養成では遮光は 行わず，強い光条件下で栽培することが挿し穂収量の増加 や苗質を維持するために好ましいこと，などが明らかと なった。 これらの知見は，わが国に挑ける夏秋ギクの親株 養成に対し有効に活用できるものと考える.

\section{摘 要}

夏秋ギク ‘精雲’ を供試し, 土耕栽培および養液栽培に よる親株養成を行い，挿し穂収量と苗質について検討した ところ，養液栽培した親株では，土耕栽培した親株と比較 して挿し穂収量が約 2 倍に増加し, 発根苗の茥長や葉数が 増加し，早期発蕾が抑制されることを確認した。一方，養 液栽培に拈ける採穂時期, 培養液濃度, 栽植密度および親 株の遮光程度が挿し穂収量と苗質に及ぼす影響について検

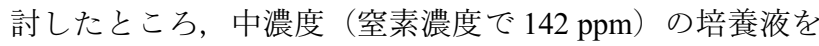
用い, 25.6 株・ $\mathrm{m}^{-2}$ の栽植密度で親株を養液栽培した場合 に挿し穂収量が最も多くなることを確認した。 また，発根 苗の茎長は採穂時期が遅く, 培養液の濃度が低いほど短く なる傾向を示すことを明らかにした。.さらに，6〜8月に かけての親株養成では，遮光は行わず，強い光条件下で栽 培することが挿し穂収量の向上や苗質を維持するために好 ましいことを示唆する結果を得た。これらの知見は，わが 国における夏秋ギクの親株養成に対し有効に活用できるも のと考える.

\section{引用文献}

Andersen, A. and L. Bertram. 1992. Physiological basis for stock 
plants effects on cuttings and post propagation growth of propagules. Acta. Hort. 314: 283-289.

Borowski, E., P. Hagen and R. Moe. 1981. Stock plant irradiation and rooting of chrysanthemum cuttings in light or dark. Sci. Hortic. 15: 245-253.

Cockshull, K. E. and A. M. Kofranek. 1985. Long-day initiation by chrysanthemum. HortScience 20: 296-298.

de Jong, J. 1981. Effects of irradiance and juvenility on the selection of chrysanthemums. Euphytica 30: 493-500.

de Ruiter. H. A. 1993. Improving cutting quality in chrysanthemum by stock plant management. Sci. Hortic. 56: 43-50.

Fischer, P. and J. Hansen. 1977. Rooting of chrysanthemum cuttings. Influence of irradiance during stock plant growth and of decapitation and disbudding of cuttings. Sci. Hortic. 7: $171-178$.

川田穣一. 1993. わが国に抢けるキク切り花生産の今後の 方向と問題点. 新花卉. 159: 9-14.

Kawata, J. and T. Toyota. 1982. The response to photoperiod and temperature in Japanese July to September flowering chrysanthemums. Acta Hort. 125: 93-99.

川田穣一・豊田 努・宇田昌義・沖村 誠・柴田道夫 ・亀 野 貞・天野正之・中村幸夫・松田健雄. 1987. キク の開花期を支配する要因. 野茶試研報. A1: 187-222.

Kofranek, A. M. 1980. Cut chrysanthemums. p. 5-41. In: Introduction to floriculture, second ed. Larson R. A. (ed.), Academic Press Inc. New York.

Machin, B. and N. Scopes. 1978. Year-round growing. p. 98101. In: Chrysanthemums. Blanford Press, Dorset, England.
Moe, R. 1988. Effect of stock plant environment on lateral branching and rooting. Acta Hort. 226: 421-430.

Röber, R. 1976. Nitrogen and potassium nutrition of chrysanthemum mother plants and their influence upon quantity and quality of cuttings. Acta Hort. 64: 47-53.

Röber, R. and G. Reuther. 1982. The influence of different $\mathrm{N}$-forms and concentrations on yield and quality of chrysanthemum cuttings. Gartenbauwissenschaft 47: 182-188.

Schoellhorn, R. K., J. E. Barrett and T. A. Nell. 1996. Branching of chrysanthemum cultivars with season, temperature, and photosynthetic photon flux. HortScience 31: 74-78.

谷川孝弘. 1999a. キク切り花生産に拈ける育苗の分業化 (その1). 苗専業経営成立のための条件. 施設園芸. 41: 48-52.

谷川孝弘. 1999b. キク切り花生産に和ける育苗の分業化 (その 2). 親株のロックウール耕による挿し穂の周年生 産. 施設園芸. 41: 50-54.

谷川孝弘. 2001. キク苗生産の現状とその効率的周年生産 技術. 施設園芸中央セミナ一. 施設園芸協会. 40-47.

谷川孝弘・小林泰生. 1991. キクの光合成に及ぼす $\mathrm{CO}_{2}$ 濃 度, 光および気温の影響. 福岡農総試研報B. 11: 57-62.

谷川孝弘・松井 洋・小林泰生. 1995. キク親株の養液栽 培 : 培養液濃度と栽植密度が挿し穂の収量および苗の 定植後の生育に及ぼす影響. 園学雑. 75 (別 2): 626-627.

Williams, K. A. and P. V. Nelson. 1992. Growth of chrysanthemum at low, relatively steady nutrient levels in a commercial-style substrate. HortScience 27: 877-880. 